\title{
Pengaruh Pengawasan Dan Pengendalian Terhadap Peningkatan Motivasi Kerja Pegawai Di Kantor Kecamatan Serang Kota Serang
}

\author{
Dyah Maharani ${ }^{1}$, Rosilawati ${ }^{2}$ \\ Sekolah Tinggi Ilmu Administrasi Maulana Yusuf Banten \\ dyah.maharani82@gmail.com, rosilawati280152@gmail.com
}

\begin{abstract}
Abstrak
Kecamatan Serang Kota Serang merupakan Kecamatan yang berada di wilayah ibu kota Provinsi Banten, dalam meningkatkan kinerja organisasi berupaya melaksanakan pengawasan dan pengendalian baik secara internal oleh pimpinan organisasi maupun secara eksternal oleh Badan atau Inspektorat, sehingga secara preventif pelaksanaan kecurangan, kesalahan dan kelalaian dapat dicegah. Kemudian dengan pengawasan dan pengendalian tersebut setiap adanya kesalahan atau kekeliruan dapat dicarikan solusinya dengan melakukan bimbingan dan pembinaan sehingga diharapkan pegawai dapat meminimalisir kekeliruan dalam melaksanakan pekerjaan, dan ini akan memberikan motivasi pegawai untuk menjalankan tugas sesuai dengan ketentuan yang berlaku. Sebagaimana telah dijelaskan pada bab terdahulu, bahwa jumlah responden dalam penelitian ini adalah sebanyak 40 orang. Adapun jumlah kuesioner sebanyak 40 eksemplar yang terdiri dari 8 pertanyaan (variabel $\mathrm{X}$ ) dan 11 pertanyaan yang menyangkut variabel terikat (variabel Y). Setelah penyebaran kuesioner dilakukan, maka kemudian dilakukan penarikan kembali dan semua kuesioner berhasil dikumpulkan. Koefisien Korelasi antar Pelaksanaan Pengawasan dan Pengendalian dengan Peningkatan Motivasi Kerja Pegawai diperoleh nilai korelasi (r) sebesar 0,996 Sedangkan t hitung sebesar 70,8 > t tabel sebesar 1,669, ini berarti terdapat hubungan yang positif dan signifikan antara Pelaksanaan Pengawasan dan Pengendalian terhadap Peningkatan Motivasi Kerja Pegawai di Kantor Kecamatan Serang Kota Serang. Sedangkan Koefisien determinasi diperoleh sebesar 99,2\% ini menandakan bahwa Pelaksanaan Pengawasan dan Pengendalian sebagai salah satu faktor yang mempengaruhi Peningkatan Motivasi Kerja Pegawai sebesar 99,2\%. Sedangkan sisanya yaitu 0,8 \% berarti ada faktor lain yang turut mempengaruhi Peningkatan Motivasi Kerja Pegawai.
\end{abstract}

Kata Kunci: pengawasan, pengendalian, motivasi kerja

\section{Pendahuluan}

Sejak bergulirnya perubahan paradigma penyelenggaraan pemerintahan dari masa lalu yang cenderung selaras dengan pendekatan top-down, maka penyelenggaraan pemerintahan di masingmasing daerah dalam melaksanakan tugas pokok dan fungsinya adalah given, yaitu bentuk yang sesuai dengan yang ditetapkan oleh Pemerintah Pusat dan mengikuti "juklak dan juknis" (petunjuk pelaksanaan dan petunjuk teknis).

Kemudian disusul dengan berputarnya roda pemerintahan dan terjadi reformasi total pada tahun 1999, karena pemerintah kurang memperoleh kepercayaan dan pengakuan masyarakat terhadap kinerja pegawai sebagai abdi Negara dan abdi masyarakat yang fokusnya waktu itu lebih besar sebagai abdi Negara dibanding dengan abdi masyarakat, maka penyelenggaraan pemerintahan

${ }^{1}$ Korespondensi: Dyah Maharani. STIA Maulana Yusuf Banten. J1. Trip K Jamaksari No.44 Kota Serang. 0254223881. dyah.maharani82@gmail.com

${ }^{2}$ Korespondensi: Rosilawati. STIA Maulana Yusuf Banten. Jl. Trip K Jamaksari No.44 Kota Serang. 0254223881. rosilawati280152@gmail.com 
berubah dari sentralistik menjadi desentralisasi, dengan harapan bahwa daerah dapat mengelola Sumber daya yang dimilikinya kemudian dapat memberikan kesejahteraan kepada masyarakat setempat. Dalam amanat reformasi mengharapkan penyelenggaraan pemerintahan dilakukan dengan tujuan untuk mencapai good governance dengan memiliki karakter akuntabilitas (accountability), Transparansi (transparency), keterbukaan (openness), dan rule of law, sehingga pendekatan top down dan keseragaman yang dianut selama ini akan tereduksi atau bahkan menghilang, karena terdapat beberapa kewenangan pusat yang diberikan kepada daerah yang akan memberikan harapan bahwa dalam era reformasi maka perubahan penyelenggaraan pemerintahan bergeser dari sentralisti menjadi desentralisasi ini dapat mewujudkan good governance atau pemerintahan yang baik. Harapan adanya pemerintahan yang baik terus diupayakan dengan adanya bermacam cara dan upaya sampai diterbitkannya Undang Undang nomor: 28 Tahun 1999 Tentang Penyelenggaraan Negara Yang Bersih dan Bebas dari Korupsi, Kolusi dan Nepotisme. Namun semua itu tidak menjadikan pelaksanaan pemerintahan daerah menjadi klin, tetapi berdasarkan opini publik, bahwa menyelenggaraan pemerintahan sekarang ini lebih chaos dengan maraknya praktek korupsi, dan kecurangan-kecurangan dalam pelaksanaan pemerintahan.

Sebagai upaya yang harus dilakukan agar penyelenggaraan pemerintahan mendapat pengakuan dari masyarakat adalah melalui pengawasan dan pengendalian sebagai wujud dari pencegahan agar tidak terjadi kecurangan-kecurangan dalam penyelenggaraan pemerintahan. Pengendalian bertujuan untuk meningkatkan akuntabilitas dan keterbukaan, juga menekankan tahapan-tahapan perbaikan atau koreksi yang objektif jika terjadi adanya perbedaan atau penyimpangan antara pelaksanaan kegiatan dengan perencanaan yang telah ditetapkan.

Terdapat beberapa tujuan dari pengendalian (pengawasan/controlling) adalah sebagai berikut:

1. Menghentikan atau neghilangkan kesalahan, penyimpangan, penyelewengan, pemborosan, hambatan, dan ketidak adilan;

2. Mencegah adanya kembali kesalahan, penyimpangan, penyelewengan, pemborosan, hambatan, dan ketidak adilan;

3. Mendapatkan cara yang lebih baik atau mempertahankan yang telah baik;

4. Menciptakan atmosfer keterbukaan, kejujuran, partisipasi, dan akuntabilitas organisasi;

5. Meningkatkan kelancaran operasi organisasi;

6. Meningkatkan kinerja organisasi;

7. Memberikan pendapat atas kinerja organisasi;

8. Mengarahkan manajemen untuk melakukan perbaikan atas masalah-masalah pencapaian kinerja yang ada;

9. Menciptakan terwujudnya pemerintahan yang bersih.

Pengawasan dan pengendalian merupakan salah satu fungsi dari manajemen dan merupakan fungsi yang terakhir, namun dalam pelaksanaannya tidak hanya dilakukan diakhir proses manajemen, tetapi juga dilakukan pada setiap proses fungsi-fungsi manajemen lainnya, sehingga pengawasan dan pengendalian akan memiliki nilai tambah bagi peningkatan kinerja organisasi. Adapun terdapat sebagian pendapat dari para ahli yang menyatakan bahwa pengawasan adalah juga pengendalian (controlling), walaupun terdapat perbedaan, pengawasan tidak diikuti dengan tindak lanjut, kalau pengendalian diikuti dengan tindak lanjut. Sebagaimana pendapat Husaini Usman menyatakan bahwa di lingkungan pemerintahah lebih banyak menggunakan istilah pengawasan dan pengendalian atau dikenal dengan WASDAL.

Dengan memperhatikan gambar di atas, bahwa pelaksanaan pengendalian diharapkan dapat melakukan tindakan korektif sehingga kesalahan dan kekeliruan dapat diantisipasi dan diperbaiki. Disamping itu dengan pengawasan dan pengendalian yang dilakukan secara berkelanjutan dan 
berkesinambungan merupakan salah satu upaya untuk meningkatkan motivasi kerja pegawai. Salah satu faktor yang dapat meningkatkan motivasi kerja adalah adanya bimbingan serta pelaksanaan pengawasan dan pengendalian sehingga pegawai akan mengetahui setiap kesalahan atau kekeliruan yang diperbuat dan kemudian dapat diberi bimbingan dan pembinaan sehingga dapat bekerja dengan memiliki dorongan yang positif dan dapat meningkatkan kinerjanya.

Kecamatan Serang Kota Serang merupakan Kecamatan yang berada di wilayah ibu kota Provinsi Banten, dalam meningkatkan kinerja organisasi berupaya melaksanakan pengawasan dan pengendalian baik secara internal oleh pimpinan organisasi maupun secara eksternal oleh Badan atau Inspektorat, sehingga secara preventif pelaksanaan kecurangan, kesalahan dan kelalaian dapat dicegah. Kemudian dengan pengawasan dan pengendalian tersebut setiap adanya kesalahan atau kekeliruan dapat dicarikan solusinya dengan melakukan bimbingan dan pembinaan sehingga diharapkan pegawai dapat meminimalisir kekeliruan dalam melaksanakan pekerjaan, dan ini akan memberikan motivasi pegawai untuk melaksanakan tugas sesuai dengan ketentuan yang berlaku. Namun dalam pelaksanaannya masih ada berbagai masalah diantaranya terlihat dari beberapa gejala masalah sebagaimana penulis ketahui pada pra penelitian, sebagai berikut:

1. Dalam melaksanakan pengawasan dan pengendalian, kurang adanya pencegahan agar tidak terulang kembali kesalahan, penyimpangan, penyelewengan, pemborosan, hambatan, dan ketidak adilan; sehingga berakibat pada kurangnya kesempatan menggunakan metode kerja;

2. Pelaksanaan pengawasan dan pengendalian kurang nampak mengarah pada pembinaan yang yang telah baik; sehingga berakibat pada kurangnya kebebasan memanfaatkan kemampuan;

\section{Landasan Pustaka}

Sebagaimana diketahui bahwa semua jenis kegiatan yang diorganisasi dan dalam semua tipe organisasi termasuk dalam praktek dimana orang-orang bekerja bersama (organisasi) untuk mencapai suatu tujuan bersama sangat membutuhkan manajemen. Dalam setiap kegiatan organisasi tanpa manajemen semua usaha akan sia-sia dan pencapaian tujuan akan jauh lebih sulit. Terdapat beberapa alasan manajemen sangat dibutuhkan dalam organisasi, sebagai berikut:

1. Untuk mencapai tujuan organisasi dan pribadi;

2. Untuk menjaga keseimbangan diantara tujuan-tujuan yang saling bertentangan dari pihakpihak yang berkepentingan dalam organisasi;

3. Untuk mencapai efisiensi dan efektivitas.

Mengingat dalam penelitian ini penulis membahas tentang pengawasan dan pengendalian yang populer disebut (WASDAL) maka untuk mengetahui arti manajemen penulis uraikan dari beberapa ahli di bawah ini.

Selanjutnya pengertian manajemen sebagaimana dikemukakan oleh H.B. Siswanto dalam bukunya Pengantar Manajemen mengutip dari beberapa ahli, sebagai berikut:

John D. Millet mengemukakan bahwa "Manajemen is the process of directing and facilitating the work of people orgazed in formal groups to achieve a desired goal (adalah suatu proses pengarahan dan pemberian fasilitas kerja kepada orang yang diorganisasikan dalam kelompok formal untuk mencapai tujuan").

Dalam hal ini Millet lebih menekankan bahwa manajemen merupakan sebagai suatu proses, yaitu serangkaian aktivitas yang mana satu dengan yang lainnya saling berurutan, secara jelas sebagai berikut:

1. Proses pengarahan (process of directing), yaitu suatu rangkaian kegiatan untuk memberikan petunjuk atau instruksi dari seorang atasan kepada bawahan atau kepada orang yang diorganisasikan dalam kelompok formal dan untuk pencapaian tujuan;

2. Proses pemberian fasilitas kerja (process of facilitating the work), yaitu rangkaian kegiatan untuk memberikan sarana dan prasarana serta jasa yang memudahkan pelaksanaan pekerjaan 
dari seorang atasan kepada bawahan atau kepada orang yang terorganisasi dalam kelompok formal untuk pencapaian suatu tujuan.

Paul Hersey dan Kenneth H. Blanchard (1980:3), mengemukakan bahwa "Management as working with and through individuals and groups to accoumplish organizational goals (suatu usaha yang dilakukan bersama individu atau kelompok untuk mencapai tujuan organisasi”,2011:1-2).

Kemudian pengertian manajemen menurut H.B. Siswanto (2011:2), menyatakan sebagai berikut: "Manajemen adalah seni dan ilmu dalam perencanaan, pengorganisasian, pengarahan, pemotivasian, dan pengendalian terhadap orang dan mekanisme kerja untuk mencapai tujuan".

Sebagaimana diketahui bahwa diantara beberapa fungsi manajemen, pengawasan dan pengendalian (controlling) memiliki peran yang sangat penting. Pengendalian (pengawasan) atau controling adalah merupakan bagian akhir dari fungsi manajemen. Fungsi manajemen yang dikendalikan adalah perencanaan, pengorganisasian, pengarahan dan pengendalian itu sendiri. Dalam fungsi pengawasan intinya adalah menetapkan mengenai apa yang harus dicapai pada periode tertentu serta tahapan untuk mencapainya. Sedangkan dalam pengendalian berusaha untuk menilai apakah tujuan dapat dicapai, dan apabila tujuan tidak dapat dicapai maka diperlukan adanya tindakan perbaikan (corrective action). Dalam pengendalian mengukur kemajuan kearah tujuan organisasi, dan memungkinkan bagi pimpinan melihat adanya penyimpangan dari perencanaan tersebut tepat pada waktunya untuk melakukan tindakan koreksi sebelum penyimpangan menjadi tidak terkendali.

Untuk lebih jelasnya, sebelum penulis mengemukakan pengertian pengawasan dan pengendalian, terlebih dahulu penulis uraikan tentang pengertian pengawasan, sebagai berikut: Viktor $\mathrm{F}$ Situmorang dan Jusuf Juhir, dalam bukunya Aspek Hukum Pengawasan Melekat Dalam Lingkungan Aparatur Pemerintah mengemukakan bahwa istilah pengawasan dalam bahasa Inggris disebut "controlling" yang diterjemahkan dengan istilah pengawasan dan pengendalian, sehingga istilah controlling lebih luas artinya dari pengawasan, (2007:18). Agar tidak salah persepsi terhadap pengertian pengawasan, penulis akan me -

nguraikan tentang pengertian pengawasan menurut beberapa pendapat para ahli sebagai berikut: Kemudian menurut pendapat S.P. Siagian dalam bukunya Filsafat Administrasi, mengemukakan bahwa: "Pengawasan adalah proses pengamatan pelaksanaan seluruh kegiatan organisasi untuk menjamin agar semua pekerjaan yang sedang dilakukan berjalan sesuai dengan rencana yang telah ditentukan sebelumnya", (1990:107).

Sedangkan Sukarno F dalam bukunya Dasar-dasar Manajemen, menyatakan bahwa "Pengawasan adalah suatu proses penentuan tentang apa yang harus dikerjakan, agar apa yang diselenggarakan sejalan dengan rencana", (1968:107) Selanjutnya pengertian pengawasan menurut Admosudirdjo (dalam Febriani, 2005:11) yang penulis unduh dari http://sambasalim.com/manajemen, mengemukakan sebagai berikut:

"controlling atau pengawasan adalah keseluruhan kegiatan untuk membandingkan atau mengukur apa yang sedang dan sudah dilaksanakan dengan kriteria, norma, standar atau rencana yang telah ditetapkan sebelumnya. Siagian (1990:107) menyebutkan bahwa pengawasan adalah: "Proses pengamatan terhadap pelaksanaan seluruh kegiatan organisasi untuk menjamin agar semua pekerjaan yang sedang dilakukan berjalan sesuai dengan rencana yang telah ditentukan sebelumnya."

Mengingat beragamnya definisi dari beberapa para ahli manajemen tentang pengawasan tersebut, maka Viktor F Situmorang dan Jusuf Juhir, dalam bukunya Aspek Hukum Pengawasan Melekat Dalam Lingkungan Aparatur Pemerintah, mengemukakan pengertian pengawasan sebagai berikut: "Pengawasan adalah setiap usaha dan tindakan dalam rangka mengetahui sejauhmana pelaksanaan tugas yang dilaksanakan menurut ketentuan dan sasaran yang ingin dicapai. Dalam definisi tersebut terdiri dari dua bagian, yaitu 1). Menggambarkan wujud dari kegiatan 
pengawasan; (2). Menggambarkan tujuan dan sasaran yang ingin dicapai oleh pengawasan tersebut", ",(1998:21).

Berdasarkan beberapa pengertian dari para ahli di atas, maka dapat disimpulkan bahwa Pengawasan adalah kegiatan untuk memperoleh kepastian apakah pelaksanaan pekerjaan/kegiatan telah dilakukan sesuai dengan perencanaan semula.

Selanjutnya menurut pendapat Robert J. Mokler (1972:2), sebagaimana dikutip oleh H.B. Siswanto dalam bukunya Pengantar Manajemen, memberikan batas pengendalian yang mengarah pada elemen esensial proses pengendalian dalam beberapa langkah. Pengertian pengendalian dimaksud sebagai berikut:

"Management control is a systematic effort to set performance standards with planning objectives, to design information feedback systems, to compare aqctual performance with these predermened standards, to determine whether there are eny deviations and to measure their significance, and to take any action required to assure that all corparate resources are being used in the most effective and efficient way possible in acchieving corporate objectives". (Pengendalian manajemen adalah usaha sistematik untuk menentukan standar kinerja dengan tujuan perencanaan, mendesain sistem umpan balik informasi, membandingkan kinerja nyata dengan standar yang telah ditetapkan, menentukan apakah ada penyimpangan dan mengukur signifikansi penyimpangan tersebut, dan menentukan tindakan perbaikan yang diperlukan untuk menjamin bahwa semua sumber daya organisasi/perusahaan yang digunakan sebisa mungkin lebih efisien dan efektif guna mencapai sasaran/tujuan organisasi”, 2011:139-140).

Selanjutnya sebagaimana dikemukakan oleh Husaini Usman dalam bukunya Manajemen Teori, Praktik, dan Riset Pendidikan mengemukakan pengertian pengawasan dan pengendalian adalah sebagai berikut. Pengendalian (Pengawasan) atau Controlling adalah bagian akhir dari fungsi manajemen. Oleh karena itu "Pengendalian adalah proses pemantauan, penilaian, dan pelaporan rencana atas pencapaian tujuan yang telah ditetapkan untuk tindakan perbaikan guna penyempurnaan lebih lanjut", (2010:503).

Mc. Farland sebagaimana dikutip oleh Maringan Marsyi Simbolon dalam bukunya Dasar-dasar Administrasi dan Manajemen, menyatakan bahwa pengawasan dan pengendalian harus berpedoman kepada hal-hal sebagai berikut:

1. Rencana (planning) yang telah ditentukan;

2. Perintah (orders) terhadap pelaksanaan pekerjaan (performance);

3. Tujuan;

4. Kebijakan yang telah ditentukan sebelumnya.

Motivasi merupakan kegiatan yang mengakibatkan, menyalurkan dan memelihara perilaku manusia. Motivasi ini merupakan subjek yang penting bagi manajer. Pada beberapa ahli yang mendefinisikan motivasi,

Sebagaimana dikemukakan Hasibuan (2007:219) dalam bukunya Manajemen Sumber Daya Manusia, mengatakan bahwa:

"Motivasi adalah pemberian daya penggerak yang menciptakan semangat kerja seseorang, agar mereka mau bekerjasama, bekerja efektif dan terintegrasi dengan segala daya upayanya untuk mencapai kepuasan. "Kemudian menurut Sudarmayanti (2011:400) motivasi sebagai berikut:

"Motivasi adalah kondisi / energi yang menggerakkan diri karyawan terarah / tertuju untuk mencapai tujuan organisasi perusahaan”. Selanjutnya menurut Irham Fahmi (2013:143) mengemukakan sebagai berikut: "Motivasi adalah aktivitas perilaku yang bekerja dalam upaya memenuhi kebutuhan-kebutuhan yang diinginkan". Menurut T. Hani Handoko (2011:252) mengemukakan penjelasan mengenai motivasi sebagai berikut:

"Motivasi yang diartikan sebagai kemantapan dalam diri seseorang yang mendorong keinginan individu untuk melakukan kegiatan tertentu untuk mencapai tujuan". 
Dari pendapat para ahli di atas maka penulis mengambil suatu kesimpulan bahwa: Motivasi adalah suatu upaya tertentu untuk menghasilkan tingkat kinerja yang diharapkan dan akan membuahkan imbalan atas kinerja tersebut.

\section{Metode Penelitian}

Sebagaimana telah dijelaskan pada bab terdahulu, bahwa jumlah responden dalam penelitian ini adalah sebanyak 40 orang. Adapun jumlah kuesioner sebanyak 40 eksemplar yang terdiri dari 8 pertanyaan (variabel X) dan 11 pertanyaan yang menyangkut variabel terikat (variabel Y). Setelah penyebaran kuesioner dilakukan, maka kemudian dilakukan penarikan kembali dan semua kuesioner berhasil dikumpulkan.

Dari seluruh kuesioner yang disebar kepada seluruh responden, dan semua kuesioner dikumpulkan, maka kuesioner ini diperiksa satu persatu untuk menilai layak atau tidaknya masing-masing kuesioner untuk dianalisis dan diberi skor sesuai dengan jawaban responden. Hasil skor tersebut direkapitulasi untuk masing-masing variabel.

Proses selanjutnya adalah meneliti keabsahan kuesioner, yakni ketepatan dalam pemberian jawaban atas pertanyaan kuesioner, dimana semua jawaban tersebut dilakukan dengan benar.

Dari hasil analisis dan pembobotan nilai jawaban dengan menggunakan Skala Likert, selanjutnya skor tersebut dihitung dengan menggunakan alat bantu MS Excel 2003 dan SPSS ver.16. Sebelum melakukan analisis nilai jawaban, maka dilakukan analisis statistik deskriptif. Teknik ini bertujuan memberikan gamabaran karakteristik semua variabel yang diteliti.

Sebanyak dua jenis data yang diungkap dalam penelitian ini secara berturut turut akan dideskripsikan sebarannya. Kedua jenis data tersebut adalah :

1. Pengawasan dan Pengendalian

2. Peningkatan Motivasi Kerja Pegawai

Sebagai bahan yang dibutuhkan dalam melaksanakan analisis ini adalah Data statistik yang meliputi data minimal, data maksimal, mean, median, modus, standar deviasi, dan varians.

\section{Hasil}

Dalam pembahasan ini penulis uraikan secara sistematis mulai dari membuat deskripsi data, Analisis Masing-Masing Item Pertanyaan dalam Variabel Bebas (Pengawasan dan Pengendalian), Analisis Masing-masing Pertanyaan dalam Variabel Terikat (Peningkatan Motivasi Kerja Pegawai), Analisis Seluruh Item Pertanyaan Variabel Bebas (Pengawasan dan Pengendalian), Analisis Seluruh Item Pertanyaan Variabel Terikat (Peningkatan Motivasi Kerja Pegawai), Uji validitas dan Reliabilitas, serta Analisis Seluruh Item Pertanyaan Variabel Bebas (Pengawasan dan Pengendalian). Untuk lebih jelasnya penulis uraikan di bawah ini.

Secara singkat deskripsi data yang dimaksudkan menyangkut skor terendah dan skor tertinggi yang secara empiris diapai oleh kedua varaibel tersebut, sehingga akan nampak rentang datanya. Selain itu juga dideskripsikan variabilitas yang menyangkut nilai rata-rata (Mean), Standar Deviasi (SD). Berikut ini secara berurutan disajikan menurut jenis data masing-masing :

1. Pengawasan dan Pengendalian

Sebagaimana telah dikemukakan sebelumnya bahwa jumlah kuesioner yang merupakan penjabaran dari indikator variabel Pengawasan dan Pengendalian (X) sebanyak 8 butir pertanyaan. Dari hasil perhitungan diketahui bahwa skor terendah 29 dan skor tertinggi 40. Dengan demikian rentang skor yang ada adalah 8 (40-29). Bila dilihat dari angka tersebut, maka angka minimum yang mungkin dapat dicapai adalah 29 sedangkan angka maksimum yang mungkin bisa dicapai adalah 40, nilai rata-rata mencapai 36,65 dan standar deviasi 2,64.

2. Peningkatan Motivasi Kerja Pegawai

Skor data variabel peningkatan Motivasi Kerja Pegawai (Y) dimana jumlah pertanyaan kuesioner sebanyak 20 butir pertanyaan. Dari hasil perhitungan diketahui skor terendah 67 
dan skor tertinggi 99. dengan demikian rentang skor terendah 67 dan skor tertinggi 99. Dengan demikian rentang skor yang ada adalah 32 (99-67). Bila dilihat dari angka tersebut, maka angka minimum yang mungkin dicapai adalah 67 sedangkan angka maksimum yang mungkin bisa dicapai adalah 99, nilai rata-rata mencapai 89,2 dan standar deviasinya 5,73.

Selanjutnya penulis akan melakukan analisis terhadap masing-masing aspek variabel dari variabel bebas (Pengawasan dan Pengendalian) dan variabel terikat ( Motivasi Kerja Pegawai ). Analisis tersebut didasarkan pada prinsip-prinsip Pengawasan dan Pengendalian dan tujuan peningkatan Motivasi Kerja Pegawai, kemudian dilakukan akumulasi dari jawaban terhadap indikatorindikator dari masing-masing variabel tersebut untuk mengetahui prosentase yang terdapat pada Kantor Kecamatan Serang Kota Serang.

Berdasarkan perhitungan di atas, koefisien korelasi (r) antara Pengawasan dan Pengendalian adalah sebesar 0,996 atau 99,6\%, berdasarkan tabel interpretasi koefisien korelasi, dapat diketahui bahwa hubungan antara Pengawasan dan Pengendalian terhadap Peningkatan Motivasi Kerja Pegawai terbukti adanya hubungan yang positif dan sangat kuat.

Dari perhitungan Koefisien penentu/koefisien diterima (KD) sebesar 99,2\% berarti pelaksanaan Pengawasan dan Pengendalian memberi kontribusi 99,2\% terhadap Peningkatan Motivasi Kerja Pegawai, sedangkan sisanya sebesar $0,8 \%$ merupakan faktor lain yang tidak ditinjau dalam penelitian ini yang ikut serta mempengaruhi Peningkatan Motivasi Kerja Pegawai yang perlu dilakukan penelitian lebih lanjut.

Persamaan regresi yang telah ditentukan tersebut dapat digunakan untuk melakukan prediksi (ramalan) berapa nilai dalam variabel terikat akan terjadi bila nilai dalam variabel bebas ditetapkan. Hal ini berarti bila kualitas Pelaksanaan Pengawasan dan Pengendalian di tingkatkan sampai nilai optimal sesuai dengan skor ideal instrumen yaitu $5 \times 40=200$, maka nilai Peningkatan Motivasi Kerja Pegawai dapat dilihat sebagai berikut:

$\hat{Y}=70,43+0,51(200)=172,43$

Jadi diperkirakan nilai Peningkatan Motivasi Kerja Pegawai menjadi 172,43 Jika nilai Pelaksanaan Pengawasan dan Pengendalian dinaikkan menjadi 200 Sehingga dari persamaan di atas dapat diartikan, bahwa bila Peningkatan Motivasi Kerja Pegawai agar bertambah 1, maka nilai rata-rata Pelaksanaan Pengawasan dan Pengendalian harus dinaikkan sebesar 70,43.

\section{Simpulan}

Dengan memperhatikan seluruh uraian dan pembahasan terdapat beberapa temuan yang dapat penulis rangkum untuk dijadikan kesimpulan, sebagai berikut:

1. Terdapat Pengaruh Pelaksanaan Pengawasan dan Pengendalian terhadap Peningkatan Motivasi Kerja Pegawai di Kantor Kecamatan Serang Kota Serang, dengan dibuktikan bahwa perolehan Pelaksanaan Pengawasan dan Pengendalian mencapai prosentase sebesar 91,63\%; dan Peningkatan Motivasi Kerja Pegawai di Kantor Kecamatan Serang Kota Serang mencapai prosentase sebesar 88,93\%;

2. Koefisien Korelasi antar Pelaksanaan Pengawasan dan Pengendalian dengan Peningkatan Motivasi Kerja Pegawai diperoleh nilai korelasi (r) sebesar 0,996 Sedangkan t hitung sebesar 70,8 > t tabel sebesar 1,669, ini berarti terdapat hubungan yang positif dan signifikan antara Pelaksanaan Pengawasan dan Pengendalian terhadap Peningkatan Motivasi Kerja Pegawai di Kantor Kecamatan Serang Kota Serang. Sedangkan Koefisien determinasi diperoleh sebesar 99,2\% ini menandakan bahwa Pelaksanaan Pengawasan dan Pengendalian sebagai salah satu faktor yang mempengaruhi Peningkatan Motivasi Kerja Pegawai sebesar 99,2\%. Sedangkan sisanya yaitu $0,8 \%$ berarti ada faktor lain yang turut mempengaruhi Peningkatan Motivasi Kerja Pegawai;

3. Persamaan regresi Pelaksanaan Pengawasan dan Pengendalian dan Peningkatan Motivasi Kerja Pegawai yaitu $\hat{Y}=70,43+0,51 X$. Selanjutnya persamaan regresi tersebut dapat 
digunakan untuk melakukan prediksi (ramalan) berapa nilai dalam variabel terikat (Pelaksanaan Pengawasan dan Pengendalian) akan terjadi bila nilai dalam variabel bebas (Peningkatan Motivasi Kerja Pegawai) ditetapkan.

\section{Referensi}

Arif, M. S. (2007). Organisasi dan Manajemen. Jakarta: Universitas Terbuka.

Dwiyanto, \& Agus dkk. (2002). Pengantar Ilmu administrasi dan Manajemen. Jakarta: PT. Gunung Agung.

Hasibuan, Malayu S.P. (2001). Manajemen Sumber Daya Manusia. Bandung: Bumi Aksara.

Mckenna, E., \& Nic, B. (2000). The Essence Of Manajemen Sumber Daya Manusia. Yogyakarta: ANDI.

Mumuh. (2005). Prestasi, Penghargaan, Kenaikan Jabatan, dan Pujian. Jakarta: Grafindo Persada.

Nur L.M., \& Mansor, A. T.. (2010). Tekanan Kerja, Motivasi dan Motivasi Kerja Tentera Laut, Armada Tentera Laut Diraja Malaysia. Jurnal Kemanusiaan. ISSN: 1675-1930

Instruksi Presiden, No.15 Tahun 1983. Tentang Pedoman Pelaksaan Pengawasan.

Instruksi Presiden, No.1 Tahun 1989. Tentang Pengawasan Melekat.

Peraturan Daerah Kota Serang, No. 03 Tahun 2009. Kecamatan dan Pembentukan Organisasi Kecamatan di Kota Serang.

Peraturan Walikota Serang, No. 42 Tahun 2009. Tentang Tugas Pokok dan Fungsi Kecamatan. http://tips-belajar-internet.blogspot.com/209/08/pengertian-pengawasan http://dansite.wordpress.com/2009/04/10/definisipengertian-Motivasi-kerja/, 